The Noodle Narratives 



\section{The Noodle Narratives}

The Global Rise of an Industrial Food into the Twenty-First Century

\section{Frederick Errington, Tatsuro Fujikura, and Deborah Gewertz}

甲 
University of California Press, one of the most distinguished university presses in the United States, enriches lives around the world by advancing scholarship in the humanities, social sciences, and natural sciences. Its activities are supported by the UC Press Foundation and by philanthropic contributions from individuals and institutions. For more information, visit www.ucpress.edu.

University of California Press

Berkeley and Los Angeles, California

University of California Press, Ltd.

London, England

(C) 2013 by The Regents of the University of California

Library of Congress Cataloging-in-Publication Data

Errington, Frederick Karl.

The noodle narratives : the global rise of an industrial food into the twenty-first century / Frederick Errington, Tatsuro Fujikura, and Deborah Gewertz.

p. $\mathrm{cm}$.

Includes bibliographical references and index. ISBN 978-0-520-27633-8 (cloth : alk. paper) ISBN 978-0-520-27634-5 (pbk. : alk. paper)

I. Noodles industry-Social aspects-Japan.

2. Noodles industry-Social aspects-United States.

3. Noodles industry-Social aspects-Papua New

Guinea. 4. Noodles-Social aspects-Japan.

5. Noodles-Social aspects-United States.

6. Noodles-Social aspects-Papua New Guinea.

I. Tatsuro, Fuzikura. II. Gewertz, Deborah B., I948- III. Title.

HD933O.M322E77 2013

$338.4^{\prime} 7664755-\mathrm{dc} 23$

2012046523

Manufactured in the United States of America

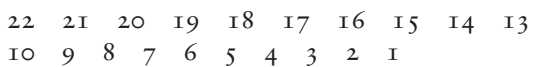

In keeping with a commitment to support environmentally responsible and sustainable printing practices, UC Press has printed this book on Rolland Enviroroo, a I0०\% post-consumer fiber paper that is FSC certified, deinked, processed chlorine-free, and manufactured with renewable biogas energy. It is acid-free and EcoLogo certified. 